\title{
Pembangunan Aplikasi Perhitungan Honor \& Pengukuran Kinerja Asisten Praktikum Berbasis SaaS
}

\author{
Fitri Susanti ${ }^{1}$, Henry Rossi Adrian ${ }^{2}$, Nota Tema Gea ${ }^{3}$ \\ ${ }^{1,2,3}$ Program Studi Teknik Komputer, Fakultas Ilmu Terapan, Universitas Telkom \\ Jln Terusan Buah Batu, Dayeuh Kolot - Bandung - Indonesia \\ fitri.susanti@tass.telkomuniversity.ac.id ${ }^{1}$, rossi@tass.telkomuniversity.ac.id ${ }^{2}$, notamcgea@ gmail.com ${ }^{3}$
}

\begin{abstract}
Abstrak - Bagi suatu perguruan tinggi, kegiatan praktikum sangat penting untuk mendukung pembelajaran di kelas. Beberapa masalah yang muncul dalam pengelolaan kegiatan praktikum seperti keterlambatan pengumpulan berita acara praktikum (BAP) sehingga memperlambat perhitungan, pembayaran dan pelaporan honor asprak. Dibutuhkan waktu sekitar dua minggu untuk rekapitulasi dan validasi ratusan lembar BAP yang telah terkumpul setiap bulannya. Dibutuhkan pengolahan data lebih lanjut untuk menilai kinerja asprak berdasarkan data BAP. Untuk mengatasi permasalahan di atas maka dibangun aplikasi perhitungan honor dan kinerja asprak. Aplikasi ini digunakan untuk mengelola data BAP, perhitungan dan pelaporan honor, perhitungan nilai transkrip aktivitas kemahasiswaan (TAK) dan pencetakan sertifikat asprak. Keterbatasan SDM atau biaya menyebabkan tidak semua perguruan tinggi dapat langsung membuat aplikasi yang dibutuhkan. Oleh karena itu aplikasi ini dibangun berbasis Software as A Service (SaaS). Aplikasi ini dikembangkan dengan metode analisis perancangan terstruktur dengan model waterfall. Pengumpulan data kebutuhan aplikasi dilakukan dengan survey ke fakultas-fakultas di Universitas Telkom. Hasilnya dianalisis dan dikembangkan menjadi rancangan aplikasi. Aplikasi diimplementasikan pada pemrograman PHP. Pengujian dilakukan dengan metode black box testing. Hasilnya berupa aplikasi SaaS untuk perhitungan honor dan pengukuran kinerja asisten praktikum. Perguruan tinggi pengguna aplikasi SaaS ini dapat melakukan kostumisasi terhadap fitur yang ada sesuai dengan kebutuhan.
\end{abstract}

Kata kunci - Asisten praktikum, BAP, honor, Software as a Service

Abstract - For a university, practicum is needed to support teaching and learning activities. Some of problems in managing practicum's activities such as delay of collecting practicum activity report which in turn slow down the calculation, payment and reporting of practicum assistant's honorarium. It takes about two weeks for recapitulation and validation of hundreds of practicum activity report. Further data processing is required to assess practicum assistant's performance based on practicum activity report. To solve such problems, a salary calculation and practicum assistant's performance assessment application is developed. This application can be used for manage practicum activity report, calculation and reporting honorarium, assess student's activity transcript, and printing assistant's certificate. Due to limited human resource and cost, not all universities can directly develop the required application. Therefore, this application is developed based on Software as a Service (SaaS). This application is developed by using structured analysis - design with Waterfall model. Identifying software requirements is done by surveyed to some different faculties in Telkom University. The result is a salary calculation and practicum assistant's performance assessment application based on SaaS. Application is implemented in PHP programming. Testing is done by black box testing. University, the user of this application can customization the functionalities according to university required.

Keywords - practicum assistant, practicum activity report, honorarium, Software as a Service

\section{PENDAHULUAN}

Menurut kamus besar Bahasa Indonesia, praktikum merupakan bagian dari pengajaran yang bertujuan agar siswa mendapat kesempatan untuk menguji dan melaksanakan di keadaan nyata tentang teori yang telah dipelajari [1]. Bagi suatu perguruan tinggi, kegiatan praktikum sangat penting untuk mendukung pembelajaran di kelas. Saat praktikum, mahasiswa dapat mempraktekkan teori-teori yang telah disampaikan oleh dosen. Praktikum umumnya dibantu oleh asisten praktikum (asprak). Pada satu semester di satu perguruan tinggi, total jumlah asprak yang direkrut untuk seluruh mata praktikum dapat mencapai ratusan orang.

Beberapa masalah yang muncul dalam pengelolaan kegiatan praktikum seperti keterlambatan pengumpulan berita acara praktikum (BAP) sehingga memperlambat proses perhitungan, pembayaran dan pelaporan honor asprak. Di beberapa perguruan tinggi, BAP masih dalam bentuk dokumen kertas. Pihak administrasi laboraorium membutuhkan waktu sekitar dua minggu untuk rekapitulasi dan validasi ratusan 
lembar BAP yang telah terkumpul setiap bulannya. Karena jumlah BAP yang direkap berjumlah ratusan, sering terjadi human error dalam proses rekapitulasi tersebut. Selain itu, dibutuhkan pengolahan data lebih lanjut untuk pembuatan sertifikat dan perhitungan transkrip aktivitas (TAK) asprak sehingga pencetakan sertifikat dan pelaporan TAK tidak tepat waktu. Untuk mengatasi permasalahan di atas maka dibangun aplikasi perhitungan honor dan kinerja asprak. Aplikasi ini digunakan untuk mengelola data BAP, perhitungan dan pelaporan honor, perhitungan nilai transkrip aktivitas kemahasiswaan (TAK) dan pencetakan sertifikat asprak.

Karena keterbatasan resource, tidak semua perguruan tinggi dapat langsung membuat aplikasi yang dibutuhkan. Oleh karena itu, aplikasi pengelolaan honor dan kinerja asprak ini dibangun berbasis Software as A Service (SaaS). SaaS merupakan salah satu layanan cloud computing dalam bentuk perangkat lunak [2], dan pengguna dapat melakukan kostumisasi aplikasi sesuai dengan kebutuhannya [2]. Software dipandang sebagai salah satu layanan yang dapat diakses oleh pengguna secara remote dan setiap saat [3].

Contoh aplikasi SaaS sejenis yang telah dikembangkan seperti aplikasi penggajian [4]. Fungsionalitas yang terdapat pada aplikasi penggajian berbasis SaaS yaitu melakukan perhitungan penggajian harian dan bulanan berdasarkan kehadiran pegawai. Aplikasi tersebut dapat dikembangkan menjadi aplikasi perhitungan honor asprak. Perbedaannya terdapat pada proses perhitungan honornya dan parameter-parameter perhitungan honornya.

Aplikasi berbasis SaaS ini dapat mengakomodir kebutuhan perguruan tinggi dalam pengelolaan kegiatan praktikum. Perguruan tinggi pengguna aplikasi ini dapat memodifikasi fitur-fitur yang terdapat di aplikasi sesuai dengan kebutuhan di perguruan tinggi tersebut.

\section{METODOLOGI PENELITIAN}

Metode yang digunakan dalam pembangunan aplikasi ini adalah dengan metode Waterfall. Permasalahan diselesaikan secara terstruktur mulai dari tahap analisis, perancangan, implementasi serta pengujian aplikasi.

\section{A. Analisis}

Pada tahap ini dilakukan studi literatur, pengumpulan informasi dan kebutuhan aplikasi. Dilakukan survey ke empat fakultas yang berbeda di lingkungan Universitas Telkom untuk mendapatkan informasi tentang proses pengelolaan kegiatan praktikum, penilaian kinerja asprak dan pihak-pihak yang terlibat pada proses tersebut. Survey dilakukan di awal perkuliahan semester genap tahun ajaran 2014/2015. Responden yang terlibat dari setiap fakultas tersebut antara lain asprak, laboran, staf administrasi laboratorium, dan Kepala Urusan Laboratorium. Dari hasil survey, dilakukan analisis perbandingan proses dan penentuan requirement aplikasi.

Karena aplikasi yang dibangun merupakan salah satu layanan Cloud Computing, maka aplikasi SaaS yang dibangun harus memenuhi karakteristik Cloud Computing yaitu [5].

\section{On-Demand Self-Service}

User dapat mengakses layanan cloud computing sesuai dengan kebutuhan, tanpa perlu dilayani oleh pihak lain (misal: teknisi atau provider Cloud Computing)

2. Pengelolaan dan update aplikasi terpusat oleh provider SaaS.

3. User bersifat hanya menggunakan aplikasi, tanpa perlu tahu di server mana aplikasi tersebut berada. Aplikasi dapat diakses melalui web browser atau web based interface.

\section{B. Perancangan}

Mengacu pada hasil analisis, pada tahap ini dilakukan perancangan proses yang ditangani, antarmuka aplikasi, penentuan hak akses setiap user dan perancangan basis data yang digunakan.

\section{Implementasi}

Hasil dari tahap perancangan diimplementasikan dalam bentuk pembuatan kode program dengan menggunakan bahasa pemrograman PHP dan framework CodeIgniter (CI). Dengan menggunakan prinsip framework $\mathrm{CI}$, saat user memberikan request ke aplikasi, maka request tersebut akan diproses melalui tiga layer yaitu.

1. Layer view: berisi kumpulan antar muka antara user dan aplikasi

2. Layer controller: layer penghubung antara layer view dan model

3. Layer model: menghubungkan aplikasi dengan database.

Keterhubungan antar layer terlihat pada Gambar 1 [6].

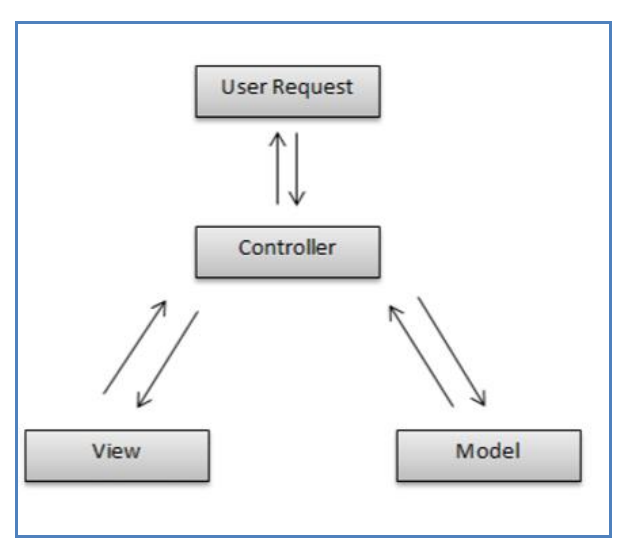

Gambar 1. Model-View-Controller [6] 
Pembangunan basis data diimplementasikan menggunakan MySQL.

\section{Pengujian}

Pada tahap ini dilakukan pengujian terhadap fungsionalitas aplikasi, memastikan fungsionalitas aplikasi sesuai dengan tujuan, perancangan yang telah ditentukan sebelumnya. Pengujian dilakukan dengan metode black-box.

\section{HASIL \& PEMBAHASAN}

Berdasarkan hasil pengumpulan kebutuhan aplikasi dan studi literatur, maka arsitektur aplikasi yang dibangun ditunjukkan seperti pada Gambar 2 .

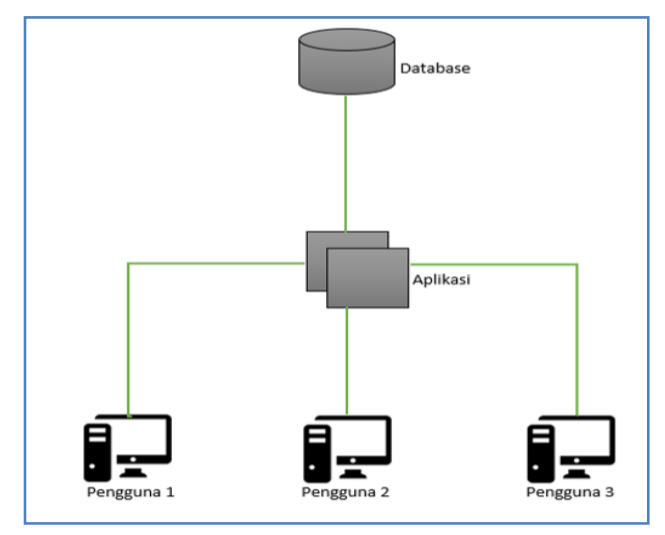

Gambar 2. Arsitektur Aplikasi

Aplikasi dibangun untuk dapat diakses oleh banyak user. Digunakan satu database terpusat untuk mengelola data kegiatan praktikum. Adapun fungsionalitas dan user yang terlibat pada aplikasi ini adalah.

1. Pengelolaan data BAP mencakup :

a. Input, edit, hapus data BAP: dilakukan oleh asprak

b. Validasi data BAP: dilakukan oleh petugas administrasi praktikum

2. Perhitungan honor asprak mencakup.

a. Perhitungan honor asprak per bulan sesuai dengan BAP yang telah divalidasi

b. Pencetakan slip honor asprak

c. Pelaporan honor asprak kepada Kepala Urusan Laboratorium

Keseluruhan poin di atas dilakukan oleh petugas administrasi praktikum

3. Pembuatan sertifikat asprak

Pencetakan sertifikat asprak dapat dilakukan sesuai dengan ketentuan-ketentuan yang berlaku pada suatu perguruan tinggi. Pencetakan dilakukan oleh petugas administrasi praktikum.

\section{Perhitungan dan Pelaporan TAK}

Kinerja asisten dinilai dari BAP dan diapresiasi dalam bentuk pemberian nilai TAK. Pemberian nilai TAK disesuaikan dengan ketentuan-ketentuan yang berlaku pada suatu perguruan tinggi. Fitur ini dikelola oleh petugas administrasi praktikum.

Secara umum, aplikasi ini terdiri dari tiga (3) kelompok user yaitu .

\section{Super admin (Admin SaaS)}

Berperan sebagai pengelola utama aplikasi dan pengembangan aplikasi. Hak akses super admin mencakup.

a. Memberikan persetujuan untuk setiap user yang mendaftar akan menggunakan aplikasi SaaS (approvel unapprove).

b. Pengelolaan data user yang telah disetujui menggunakan aplikasi SaaS.

c. Kelola fungsionalitas aplikasi.

2. Admin

Merupakan user yang menggunakan aplikasi SaaS ini. Untuk dapat menggunakan layanan pada aplikasi SaaS ini, admin terlebih dahulu mendaftarkan perguruan tinggi nya untuk menggunakan aplikasi ini. Hak akses admin adalah .

1. Mendaftarkan dan mengelola data seluruh end user pengguna fitur-fitur aplikasi SaaS yang ada di perguran tinggi nya.

2. Melakukan kostumisasi fitur-fitur aplikasi

\section{End User}

End User terdiri dari: asprak, Kaur Laboratorium, Laboran atau petugas administrasi praktikum yang telah didaftarkan oleh Admin. berikut.

Alur proses penggunaan aplikasi SaaS ini sebagai

1. Admin mendaftar untuk menggunakan aplikasi SaaS

2. Super admin memberikan persetujuan kepada admin yang telah mendaftar

3. Admin yang telah disetujui dapat mengkases aplikasi, mendaftarkan dan memberikan hak akses untuk user yang akan menggunakan aplikasi SaaS ini seperti asprak, laboran, kepala urusan laboratorium dan lain sebagainya.

4. Setiap end user mengakses aplikasi sesuai dengan hak akses yang diberikan 
Adapun rancangan logik basis data dituangkan dalam diagram Entity Relationship seperti ditunjukkan

pada Gambar 3.

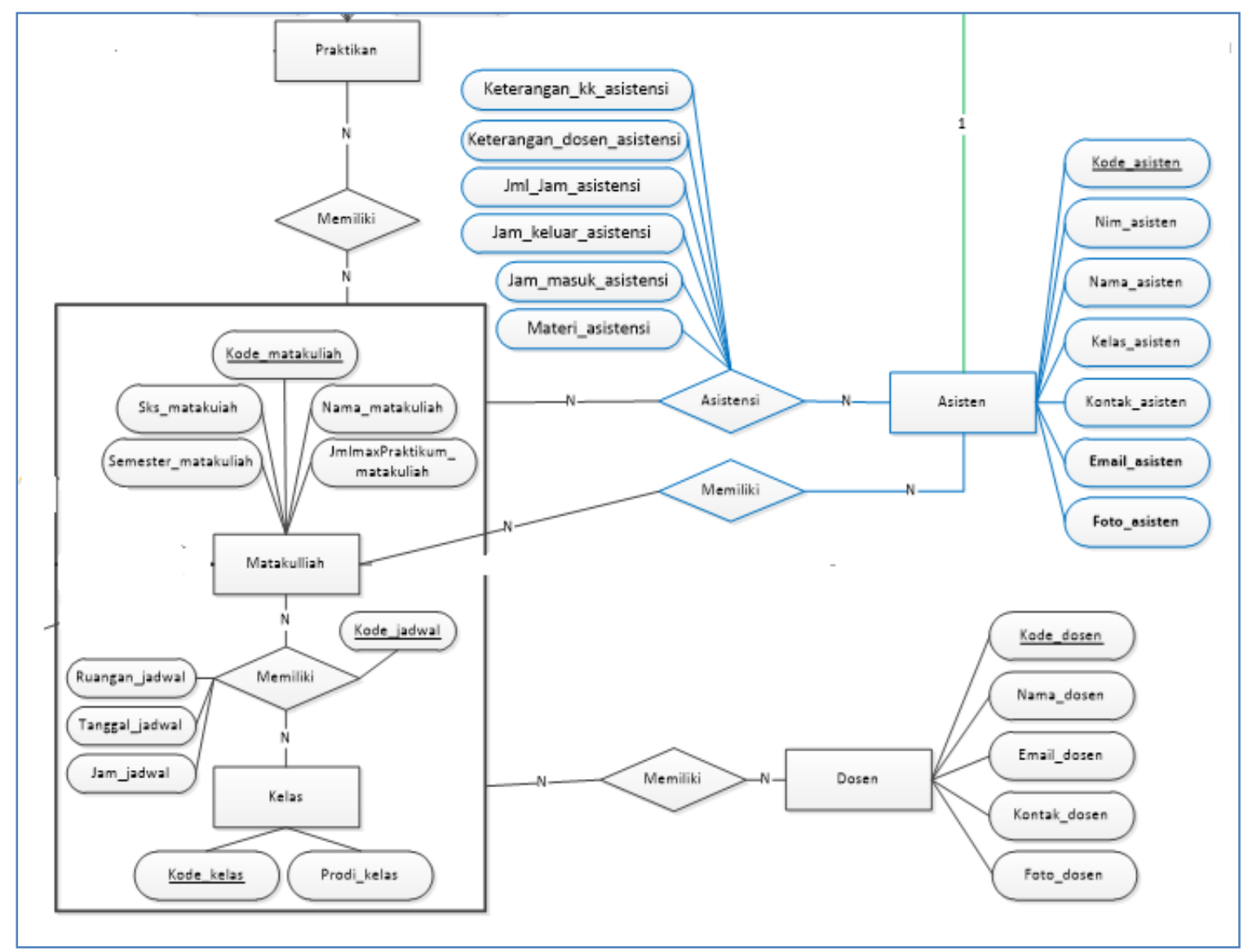

Gambar 3. Diagram Entity Relationship

Pada digram Entity Relationship di atas, terdapat entitas asisten, dosen, matakuliah, kelas dan praktikan. Entitas asisten berisi keseluruhan data asprak, berelasi dengan agregasi matakuliah dan kelas. Pada relasi asistensi tersebut dicatat seluruh data pelaksanaan praktikum. Pengolahan data BAP sebagian besar diambil dari data yang terdapat pada relasi asistensi tersebut. Entitas dosen mencatat data dosen yang memiliki matakuliah praktikum. Entitas praktikan berisi data mahasiswa yang mengambil matakuliah praktikum.

Pada implementasi database, selain digunakan tabel-tabel sesuai dengan diagram Entity Relationship diatas, juga digunakan tabel admin dan tabel end user yang dikelola oleh setiap admin.

Berikut contoh antarmuka yang mewakili setiap proses utama pada aplikasi SaaS ini.

1. Form registrasi untuk menggunakan aplikasi

Form registrasi aplikasi berisi data-data yang harus diisi oleh calon admin yang akan menggunakan aplikasi SaaS ini. Data yang diminta mencakup username, nama, alamat, fakultas, dan password. Berdsarkan data calon admin yang telah registrasi, super admin akan memberikan persetujuan penggunaan aplikasi. Antarmuka super admin untuk memberikan persetujuan bagi user yang mendaftar untuk menggunakan aplikasi seperti ditunjukkan pada Gambar 4.

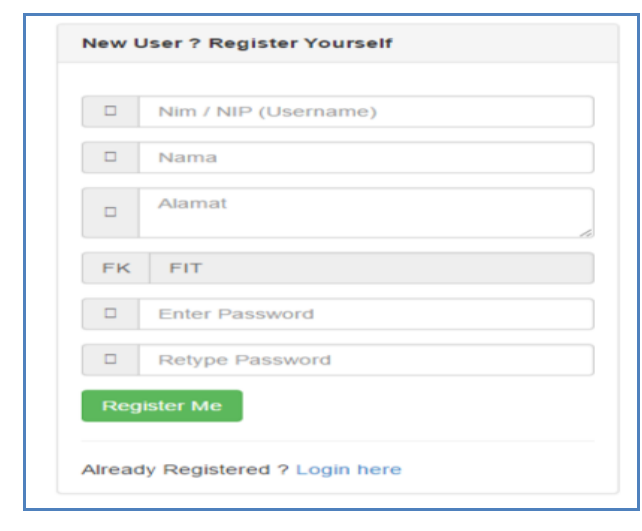

Gambar 4. Form Registrasi Aplikasi

Pada Gambar 5 ditampilkan daftar calon admin yang telah mengisi form registrasi. Jika telah disetujui oleh super admin, admin dapat melakukan kostumisasi form-form yang ditampilkan, contohnya seperti yang ditunjukkan pada Gambar 6. 


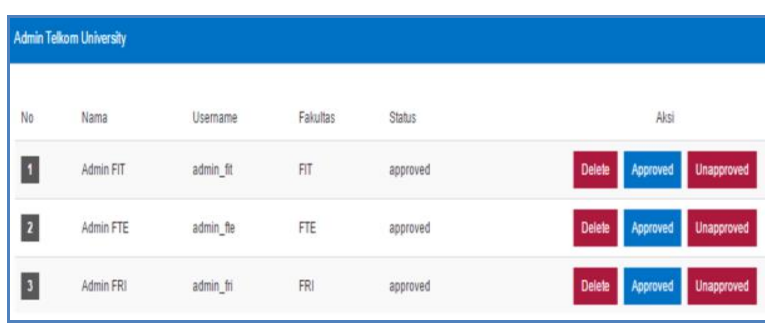

Gambar 5. Persetujuan user pengguna aplikasi

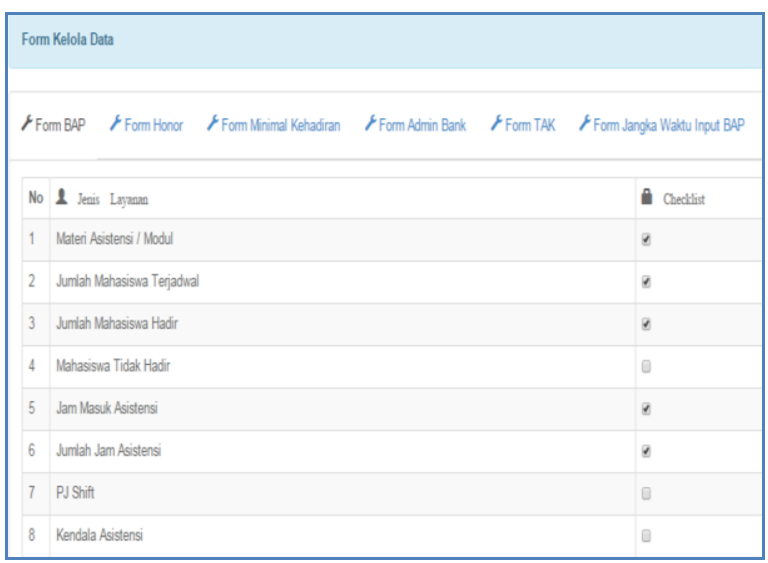

Gambar 6. Contoh Kostumisasi Form

Pada Gambar 6, tampil contoh data yang dapat dimodifikasi oleh admin, seperti: materi asistensi, jumlah mahasiswa terjadwal, jumlah mahasiswa yang hadir. Tanda centang dan yang tidak dicentang menunjukkan parameter tersebut muncul / tidak muncul pada form yang akan digunakan.

2. Contoh antarmuka untuk kelola data end user yang dilakukan oleh admin

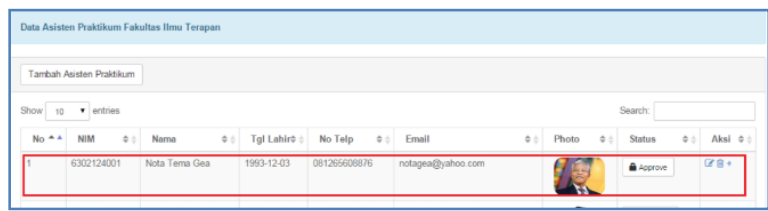

Gambar 7. Kelola Data End-User

Admin dapat menambahkan/mengubah end user pada aplikasi yang dikelolanya melalui antar muka seperti pada Gambar 7.

3. Antarmuka input Berita Acara Praktikum (BAP) oleh asprak

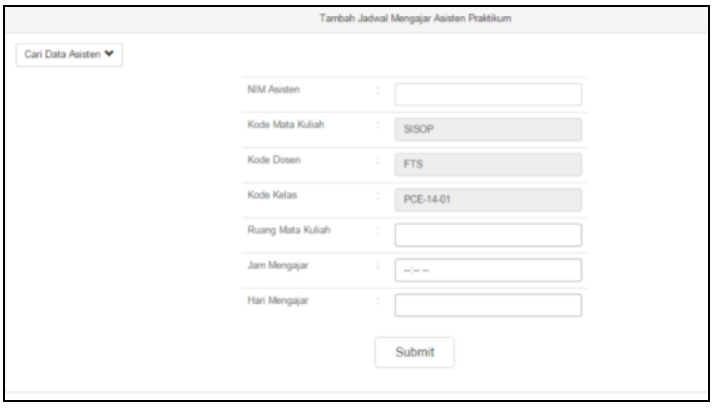

Gambar 8. Contoh Input Berita Acara Praktikum (BAP)

Setiap selesai pelaksanaan praktikum, asprak mengisi BAP. Data hasil pengisian BAP diolah lebih lanjut menjadi perhitungan honor dan TAK asprak. BAP yang diminta mencakup NIM asprak, kode mata kuliah yang diasistensi, kode dosen, kode kelas yang diajar, ruangan praktikum, dan jadwal praktikum

BAP yang telah direkap direkapitulasi setiap bulannya. Berikut contoh antarmuka hasil rekapitulasi data BAP asisten praktikum

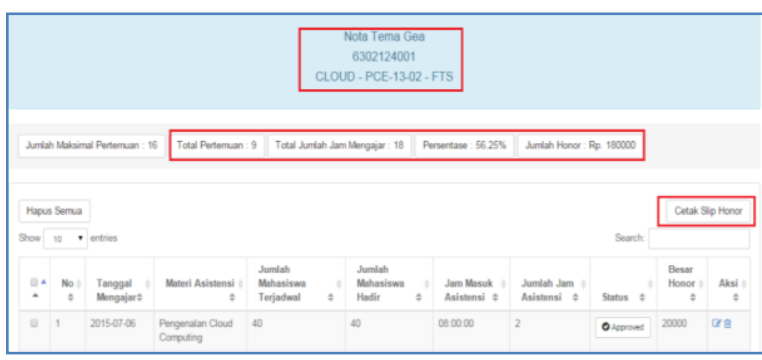

Gambar 9. Rekapitulasi BAP Asprak

Hasil pengolahan data pelaksanaan praktikum oleh asprak ditampilkan dalam bentuk tabel seperti pada gambar diatas. Selain menampilkan rekapitulasi pelaksanaan praktikum, ditampilkan juga hasil perhitungan honor yang diperoleh oleh setiap asprak.

Rekapitulasi honor juga dapat diakses oleh Kepala Urusan Laboratorium. Antarmuka pelaporan honor (dalam bentuk grafik) seperti ditunjukkan pada Gambar 10,

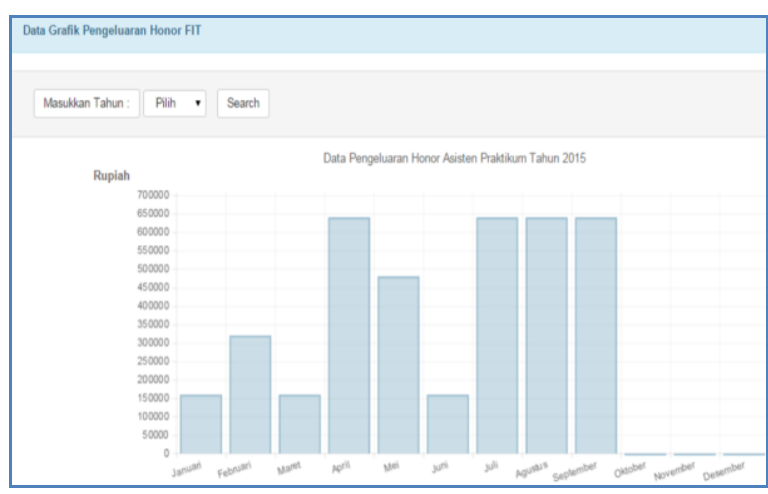

Gambar 10. Rekapitulasi BAP Asprak 
Untuk setiap bulannya, Kepala Urusan Laboratorium dapat melihat grafik penggunaan anggaran laboratorium untuk penggajian asprak.

4. Contoh laporan slip gaji yang diterima oleh asprak

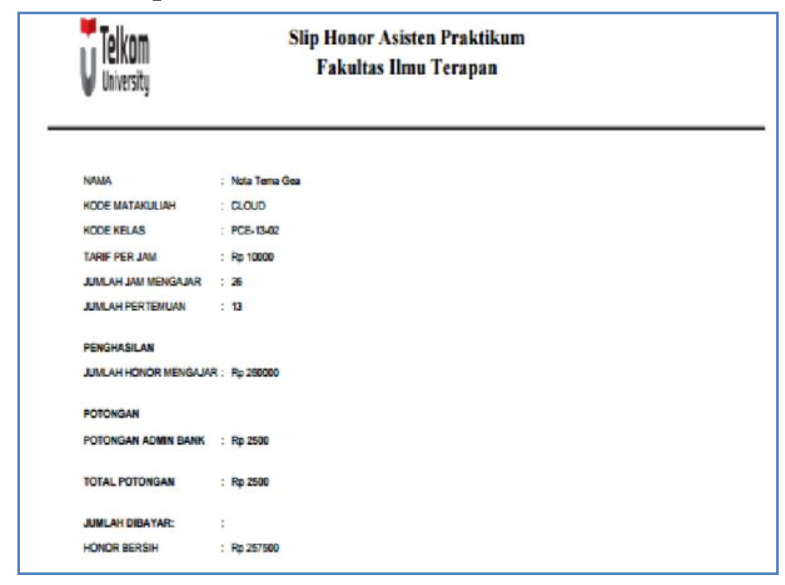

Gambar 11. Slip Gaji Asprak

Gambar 11 merupakan contoh laporan slip gaji yang diterima oleh setiap asprak. Terdapat informasi total jam praktikum yang telah dilaksanakan, total honor, potongan pajak (administrasi bank) dan jumlah akhir yang diterima oleh asprak.Pengujian fungsionalitas aplikasi dengan menggunakan metode black box. Hasil pengujian adalah semua fungsionalitas aplikasi telah tercapai. Resume hasil pengujian seperti pada tabel berikut .

\begin{tabular}{clc}
\multicolumn{3}{c}{ Tabel 1. Resume Hasil Pengujian Black Box } \\
\hline No & \multicolumn{1}{c}{ Fungsionalitas } & Hasil \\
\hline 1 & Kelola user, admin, end user & Berhasil \\
2 & Pengelolaan data BAP & Berhasil \\
3 & Perhitungan honor asprak & Berhasil \\
4 & Pencetakan slip honor asprak & Berhasil \\
5 & Pelaporan honor asprak & Berhasil \\
6 & Pembuatan sertifikat asprak & Berhasil \\
7 & Perhitungan TAK & Berhasil \\
8 & Pelaporan TAK & Berhasil \\
\hline
\end{tabular}

\section{PENUTUP}

\section{A. Kesimpulan}

Kesimpulan dari penelitian ini yaitu aplikasi perhitungan honor dan kinerja asisten praktikum berbasis SaaS telah berhasil dibangun dengan fungsionalitas: pengelolaan data BAP, perhitungan dan pelaporan honor asprak, perhitungan TAK dan pembuatan sertifikat asprak. Seluruh fungsionalitas telah tercapai. Fungsionalitas aplikasi dapat dikostumisasi oleh pengguna sesuai dengan kebutuhan. Aplikasi terdiri dari tiga kategori user yaitu super admin, admin dan end-user. Setiap kategori user memiliki hak akses tertentu.

\section{B. Saran}

Untuk pengembangan aplikasi lebih lanjut, diharapkan kostumisasi fungsionalitas aplikasi dapat dikembangkan lebih fleksibel lagi. Survey pengumpulan requirement aplikasi dapat dilakukan lebih luas lagi ke banyak perguruan tinggi sehingga aplikasi dapat mengakomodir perbedaan kebutuhan dan proses perhitungan honor dan pengukuran kinerja asprak.

\section{DAFTAR PUSTAKA}

[1] Kamus Besar Bahasa Indonesia (KBBI), available at: http://kbbi.web.id/

[2] John Rhoton, "Cloud Computing Explained", Recursive Press: USA, 2009.

[3] Sofana, Iwan, "Cloud Computing, Teori dan Praktek (Open Nebula, VMWare, dan Amazon AWS)", Informatika : Bandung, 2012.

[4] Andi Prasetyo Utomo, "Penerapan Konsep SaaS Pada Aplikasi Penggajian”, SIMETRIS, vol 6 No 1, 2015.

[5] Erick A Marks, Bob Lozano, "Executive's Guide to Cloud Computing", Jhon Wiley \& Sons, Inc : New Jersey, 2010.

[6] Awan Pribadi Basuki, Membangun Web berbasis PHP dengan Framework CodeIgniter. Yogyakarta, Indonesia: Lokomedia, 2010. 